\title{
EDUKASI SEKSUALITAS/REPRODUKSI ANAK PENYANDANG DISABILITAS PADA PEGAWAI PANTI SOSIAL MENUJU PROFESIONALITAS PELAYANAN
}

\author{
Dwi Novrianda, Hermalinda, Deswita \\ Fakultas Keperawatan Universitas Andalas \\ e-mail: deakbari.dn@gmail.com
}

\begin{abstract}
Social Institution Bina Grahita Harapan Ibu (PSBGHI) is the only social institution in West Sumatra Province who provide social services and rehabilitation for people with mental disabilities. Persons with disabilities who are in the shelter are from various districts / cities in West Sumatra which amounted to 100 people. This orphanage is located in Kalumbuk, Padang City with an area of 5,007 m2. Since the implementation of regional autonomy, PSBGHI employees totaling 44 people either civil servants and honorarium received minimally training, seminars, even a refresher material. Partners in this IbM classified into 2 groups: 1) group of civil power as many as 24 people, with educational background is not a disability, and 2) a group of honorary staff of 20 people. Problems formulated partners namely the lack of knowledge about reproduction and sexuality in the development of persons with disabilities, reproductive problems / sexuality of persons with disabilities, and to tackle the problem. Results showed an increase understanding of sexuality and handling of sexuality problems encountered in children with disabilities. Therefore, the provision of material and playback video in the form of seminar is one alternative that can be given.
\end{abstract}

Keywords : disability, seminars, PSBGHI

\begin{abstract}
Abstrak
Panti Sosial Bina Grahita Harapan Ibu (PSBGHI) merupakan satu-satunya panti sosial di Propinsi Sumatera Barat yang memberikan pelayanan dan rehabilitasi sosial bagi penyandang cacat mental (disabilitas). Penyandang disabilitas yang terdapat di panti ini berasal dari berbagai kabupaten/kota di Propinsi Sumatera Barat yang berjumlah 100 orang. Panti ini berlokasi di Kalumbuk, Kota Padang dengan luas area $5.007 \mathrm{~m}^{2}$. Semenjak pemberlakuan otonomi daerah, pegawai PSBGHI yang berjumlah 44 orang baik PNs maupun honor sangat minim sekali memperoleh pelatihan, seminar, bahkan penyegaran materi. Mitra pada IbM ini diklasifikasikan atas 2 kelompok yaitu 1) kelompok tenaga PNS sebanyak 24 orang, dengan latar pendidikan bukan disabilitas, dan 2) kelompok tenaga honorer sebanyak 20 orang. Permasalahan mitra yang dirumuskan yaitu minimnya wawasan tentang perkembangan reproduksi dan seksualitas pada penyandang disabilitas, permasalahan reproduksi/seksualitas penyandang disabilitas, dan penanganan permasalahannya. Hasil menunjukkan terjadi peningkatan pemahaman tentang perkembangan seksualitas dan upaya penanganan permasalahan yang ditemui pada anak penyandang disabilitas. Oleh karena itu pemberian materi dan pemutaran video dalam bentuk seminar merupakan salah satu alternatif yang dapat diberikan.
\end{abstract}

Kata kunci : disabilitas, seminar, PSBGHI

\section{PENDAHULUAN}

Keberadaan sebuah panti sosial tuna grahita sebagai wadah bagi penyandang disabilitas sangatlah penting. Dengan demikian hendaknya suatu panti memiliki potensi untuk merespon permasalahan kesejahteraan sosial penyandang disabilitas dan bekerja secara profesional dalam menangani berbagai permasalahan sosial penyandang disabilitas. Selanjutnya, suatu panti hendaknya melakukan upaya peningkatan kualitas pelayanan dan rehabilitasi sosial bagi penyandang disabilitas. Potensi 
tersebut tentunya dapat dicapai melalui dukungan sumberdaya manusia penyelenggara pelayanan dan rehabilitasi sosial yang proaktif, inovatif, dan profesional. Oleh karena itu, sumberdaya manusia tersebut harus memiliki pemahaman tentang permasalahan sosial penyandang disabilitas serta memiliki sikap dan perilaku yang mendukung tercapainya kemandirian dan kesejahteraan sosial penyandang disabilitas.

Dasar diadakannya sebuah institusi khusus bagi penyandang disabilitas dalam hal ini Panti Sosial Tuna Grahita disebabkan oleh kehadiran penyandang disabilitas tidak diterima keluarganya dan keluarga tidak sanggup merawat (karena kemampuan terbatas). Soemantri (2007) juga mengatakan bahwa anak penyandang disabilitas intelektual jarang diterima atau sering ditolak oleh kelompoknya. Di panti tersebut, penyandang disabilitas akan mendapat perawatan medis dan diberikan keterampilan sesuai dengan kemampuan masing-masing. Oleh karena itu diperlukan sumberdaya manusia yang kompeten memberikan metode layanan rehabilitasi sosial melalui proses refungsionalisasi dan pengembangan untuk memungkinkan penyandang disabilitas dalam hal ini tunagrahita mampu melaksanakan fungsi sosialnya secara wajar dalam kehidupan masyarakat (Efendi, 2006).

Panti Sosial Bina Grahita Harapan Ibu (PSBGHI) di Kalumbuk, Padang merupakan satusatunya panti sosial di Propinsi Sumatera Barat yang memberikan pelayanan dan rehabilitasi sosial bagi penyandang cacat mental (disabilitas) yang diklasifikasikan atas mental debil (mampu didik) dan imbisil (mampu latih). Jumlah penyandang disabilitas yang terdapat di PSBGHI saat ini adalah 100 orang, baik laki-laki maupun perempuan, berusia 13 sampai dengan 30 tahun. Penyandang disabilitas yang terdapat di panti ini berasal dari berbagai kabupaten/kota di Propinsi Sumatera Barat. Panti ini berlokasi di Kalumbuk, Kota Padang dengan luas area $5.007 \mathrm{~m}^{2}$ dengan luas bangunan $1.587 \mathrm{~m}^{2}$ dan sisanya merupakan area lapangan olah raga dan parkir kendaraan.

UPTD Panti Sosial Bina Grahita (PSBG) Harapan Ibu, Kalumbuk Padang dibangun pada tahun anggaran 1979/1980 dan dioperasionalkan mulai tanggal 26 Nopember 1981. Berdasarkan Keputusan Gubernur Nomor 32 Tahun 2003 tentang Perubahan Atas Keputusan Gubernur Sumatera Barat Nomor 22 Tahun 2001 tentang Pembentukan Organisasi dan Tata Kerja Unit Pelaksana Teknis Dinas (UPTD) Provinsi Sumatera Barat, maka PSBGHI Padang bertanggung jawab kepada Kepala Dinas Sosial Provinsi Sumatera Barat dan berada di bawah pimpinan Kepala Eselon II. Lebih lanjut, sumberdaya manusia penyelenggara pelayanan terdiri dari 24 orang Pegawai Negeri Sipil (PNS) yang terdistribusi mulai dari golongan I, II, III, dan IV serta 19 orang tenaga honorer dan 1 orang Pegawai Tidak Tetap (PTT) (Dinas Sosial Provinsi Sumatera Barat, 2014). Menurut Kepala PSBGHI untuk memberikan pelayanan kepada 100 orang kelayan (penyandang disabilitas) secara profesional maka sumberdaya manusia yang ada masih sangat terbatas baik dari segi jumlah maupun strata pendidikan dan pengetahuan. 
Sebelum tahun 2000 PSBGHI bertanggung jawab langsung kepada Kementerian Sosial Republik Indonesia (Kemensos RI). Selama masa tersebut untuk meningkatkan potensi sumberdaya manusia penyelenggara pelayanan, PSBGHI dilibatkan dalam kegiatan pelatihan dan seminar yang diadakan oleh Kemensos RI melalui pengiriman staf untuk mengikuti kegiatan tersebut. Namun menurut Kepala UPTD PSBG Harapan Ibu semenjak pemberlakuan otonomi daerah di tahun 2000 pegawai-pegawai baik PNS, honor, dan PTT sangat minim sekali memperoleh pelatihan, seminar, bahkan penyegaran materi. Di samping itu Kepala UPTD PSBGHI mengatakan bahwa para pegawai juga perlu diberikan wahana penyegaran di alam bebas untuk membentuk dan membangunkan kembali karakter pendidik dan pemberi layanan bagi penyandang disabilitas serta menjalin kekompakan dan kebersamaan di antara para pegawai UPTD PSBGHI. Pemberian materi dalam bentuk seminar merupakan salah satu alternatif yang dapat diberikan.

\section{METODE}

Permasalahan yang muncul di Panti Sosial Bina Grahita Harapan Ibu (PSBGHI) dapat dikelola dengan melihat potensi yang dimiliki yaitu ketersediaan sumberdaya manusia, fasilitas pendukung, dan jasa layanan yang ditawarkan serta keberadaannya sebagai satu-satunya panti sosial yang bergerak di bidang tunagrahita di Provinsi Sumatera Barat. Ditilik dari sumberdaya manusia, pegawai panti memiliki semangat belajar yang baik dimana mereka belajar secara mandiri untuk mendalami disabilitas. Lebih lanjut ketersediaan fasilitas pendukung akan berpengaruh pada kemampuan panti dalam pemenuhan kebutuhan pelayanan penyandang disabilitas.

Mekanisme dan rancangan aktivitas yang dilaksanakan dalam program IbM ini bertujuan untuk meningkatkan profesionalitas dan kualitas pelayanan yang diberikan oleh tenaga pendidik, tenaga sosial, dan tenaga kesehatan yang bekerja di PSBG Harapan Ibu. Pelaksanaan IbM terdiri atas 4 tahap, yaitu persiapan, pelaksanaan dan pengawasan, evaluasi kegiatan, dan rencana tindak lanjut.

Pada tahapan persiapan aktivitas yang dilakukan adalah membentuk tim task force IbM, sosialisasi program pada semua unsur terkait, pembagian tugas, menjalin kerjasama dengan pihak terkait, menetapkan narasumber, dan penentuan tempat dan waktu pelatihan. Tahap berikutnya adalah pelaksanaan. Adapun metode pelaksanaan kegiatan yang ditawarkan untuk mengatasi permasalahan tersebut adalah pemberian materi melalui seminar. Sutaat dkk (2012) merekomendasikan bahwa perlunya pembinaan pengetahuan dan keterampilan (upgrading) pekerja sosial panti. Upgrading tersebut berupa pendidikan dan pelatihan spesialisasi sesuai dengan kebutuhan penyandang disabilitas.

Kualifikasi narasumber dalam pelatihan ini adalah:

a. Latar belakang pendidikan minimal S2.

b. Memiliki pengalaman untuk melatih tentang pelayanan bagi penyandang disabilitas.

c. Berasal dari instansi yang berbadan hukum di bawah 
lingkungan Kementerian

Kesehatan Republik Indonesia dan Kementerian Riset, Teknologi dan Pendidikan Tinggi.

Materi yang diberikan adalah perkembangan reproduksi/seksual penyandang disabilitas, permasalahan reproduksi/seksual yang dihadapi penyandang disabilitas serta upaya penanganannya, dan peran tenaga keperawatan bagi penyandang disabilitas. Bentuk kegiatan adalah ceramah, pemutaran video dan diskusi.

Pada tahap evaluasi dilakukan aktivitas yang bertujuan untuk menilai keberhasilan program terhadap indikator kinerja yang ditetapkan dan menilai kesesuaian antara tujuan dengan output yang dihasilkan. Evaluasi dilakukan setelah semua program selesai dilakukan oleh tim task force.

Pada tahap akhir, aktivitas yang akan dilakukan adalah menyusun perencanaan tindak lanjut apabila dari hasil evaluasi terdapat kendala yang mengakibatkan indikator kinerja tidak tercapai sesuai dengan target yang ditentukan.

\section{HASIL \& PEMBAHASAN}

Berikut ini merupakan uraian tahap kegiatan pengabdian masyarakat berupa seminar:

1. Tahap Persiapan
a. Pengembangan pengabdian masyarakat
b. Penentuan narasumber berdasarkan kualifikasi yang telah ditetapkan
c. Menghubungi narasumber untuk penentuan jadwal dan materi seminar
d. Pengurusan administrasi ke lokasi mitra

2. Tahap Pelaksanaan

a. Persiapan: koordinasi dengan mitra, persiapan alat dan bahan, perbanyakan handout materi, dan menyebarkan undangan ke peserta

b. Pelaksanaan: Pendataan peserta, pembukaan, penyampaian materi oleh narasumber, pemutaran video, diskusi, penutupan

Setelah peserta seminar berada di ruangan, maka dilakukan pendataan untuk mengetahui karakteristik peserta, kondisi pengetahuan dan sikap peserta tentang pendidikan seks bagi penyandang disabilitas. Hasil pendataan dapat dilihat pada tabel di bawah ini. 
Tabel 1. Distribusi frekuensi karakteristik peserta seminar berdasarkan usia, jenis kelamin, status pernikahan, agama, dan pendidikan $(n=36)$

\begin{tabular}{|c|c|c|}
\hline No. & Karakteristik & $\mathbf{f}(\%)$ \\
\hline 1. & $\begin{array}{l}\text { Jenis Kelamin } \\
\text { a. Laki-laki } \\
\text { b. Perempuan } \\
\end{array}$ & $\begin{array}{l}15(42) \\
21(58) \\
\end{array}$ \\
\hline 2. & $\begin{array}{l}\text { Usia } \\
\text { a. } 25-30 \text { tahun } \\
\text { b. } 31-39 \text { tahun } \\
\text { c. } 40-49 \text { tahun } \\
\text { d. 50-59 tahun } \\
\text { e. }>60 \text { tahun }\end{array}$ & $\begin{array}{c}6(16,7) \\
14(38,9) \\
8(22,2) \\
8(22,2) \\
0(0)\end{array}$ \\
\hline 3. & $\begin{array}{l}\text { Status pernikahan } \\
\text { a. Belum menikah } \\
\text { b. Menikah }\end{array}$ & $\begin{array}{c}3(8,3) \\
33(91,7)\end{array}$ \\
\hline 4. & $\begin{array}{l}\text { Agama } \\
\text { a. Islam } \\
\text { b. Non-Islam } \\
\end{array}$ & $\begin{array}{c}36(100) \\
0(0)\end{array}$ \\
\hline 5. & $\begin{array}{l}\text { Pendidikan } \\
\text { a. SMA } \\
\text { b. Diploma/S1 } \\
\text { c. S2/S3 }\end{array}$ & $\begin{array}{c}5(13,9) \\
28(77,8) \\
3(8,3) \\
\end{array}$ \\
\hline $\begin{array}{l}\text { B } \\
\text { menunj } \\
\text { sebagia } \\
\text { kelamir } \\
\text { terbany } \\
31-39 \mathrm{t} \\
\% \text { ) di } \\
\text { tahun d } \\
\text { yaitu } \mathrm{n}\end{array}$ & $\begin{array}{l}\text { dasarkan tabel di atas } \\
\text { kan bahwa lebih dari } \\
(58 \%) \text { peserta berjenis } \\
\text { perempuan. Peserta } \\
\text { berada pada rentang usia } \\
\text { un sebanyak } 14 \text { orang }(38,9 \\
\text { uti kelompok usia } 40-49 \\
50-59 \text { tahun sama banyak } \\
\text { sing-masing } 8 \text { orang }(22,2\end{array}$ & $\begin{array}{l}\%) \text { dan kelompok usia } 25-30 \text { tahun } \\
\text { sebanyak } 6 \text { orang }(16,7 \%) \text {. } \\
\text { Umumnya peserta berstatus menikah } \\
(91,7 \%) \text { dan seluruh peserta } \\
\text { beragama Islam }(100 \%) \text {. Lebih } \\
\text { lanjut lebih dari } 3 / 4 \text { peserta memiliki } \\
\text { pendidikan sarjana, diikuti SMA dan } \\
\text { level pascasarjana, } 13,9 \% \text { dan } 8,3 \% \\
\text { secara berurutan. }\end{array}$ \\
\hline
\end{tabular}


Tabel 2. Distribusi frekuensi pengetahuan dan sikap peserta tentang pendidikan seks bagi anak disabilitas

\begin{tabular}{|c|c|c|}
\hline No. & Pertanyaan & $\mathbf{f}(\%)$ \\
\hline 1. & $\begin{array}{l}\text { Seberapa tahu Bapak/Ibu mengetahui } \\
\text { tentang pendidikan seks pada anak } \\
\text { penyandang disabilitas } \\
\text { a. Sangat tahu } \\
\text { b. Tahu } \\
\text { c. Kurang tahu } \\
\text { d. Tidak tahu } \\
\text { e. Sangat tidak tahu }\end{array}$ & $\begin{array}{c}0(0) \\
2(5,5) \\
19(52,8) \\
15(41,7) \\
0(0)\end{array}$ \\
\hline 2. & $\begin{array}{l}\text { Pendidikan seks tepat diberikan pada anak } \\
\text { penyandang disabilitas } \\
\text { a. Sangat setuju } \\
\text { b. Setuju } \\
\text { c. Kurang setuju } \\
\text { d. Tidak setuju } \\
\text { e. Sangat tidak setuju }\end{array}$ & $\begin{array}{c}0(0) \\
1(2,8) \\
6(16,7) \\
29(80,5) \\
0(0)\end{array}$ \\
\hline 3. & $\begin{array}{l}\text { Hambatan terbesar dalam melakukan } \\
\text { pendidikan seks pada anak penyandang } \\
\text { disabilitas: } \\
\text { a. Kebijakan sekolah } \\
\text { b. Budaya } \\
\text { c. Orang tua } \\
\text { d. Kurangnya pengetahuan } \\
\text { e. Agama }\end{array}$ & $\begin{array}{c}2(5,5) \\
32(88,9) \\
0(0) \\
2(5,5) \\
0(0)\end{array}$ \\
\hline 4. & $\begin{array}{l}\text { Seberapa penting pendidikan seks diberikan } \\
\text { pada anak penyandang disabilitas } \\
\text { a. Sangat penting } \\
\text { b. Penting } \\
\text { c. Kurang penting } \\
\text { d. Tidak penting } \\
\text { e. Sangat tidak penting }\end{array}$ & $\begin{array}{c}0(0) \\
5(13,9) \\
0(0) \\
31(86,1) \\
0(0)\end{array}$ \\
\hline 5. & $\begin{array}{l}\text { Informasi tentang pendidikan seks bagi } \\
\text { penyandang disabiltas diperoleh dari: } \\
\text { a. Membaca buku dan/atau majalah } \\
\text { b. Menonton siaran televisi } \\
\text { c. Pencarian internet } \\
\text { d. Seminar }\end{array}$ & $\begin{aligned} 12 & (33,3) \\
2 & (5,5) \\
20 & (55,6) \\
2 & (5,5)\end{aligned}$ \\
\hline
\end{tabular}

Tabel 2 menunjukkan bahwa umumnya peserta kurang dan tidak tahu tentang pendidikan seks pada anak penyandang disabilitas $(52,8 \%$ dan $41,7 \%$ ). Hampir seluruh peserta menyatakan tidak setuju bahwa pendidikan seks tepat diberikan pada anak disabilitas $(80,5 \%)$. Peserta umumnya mengungkapkan bahwa budaya merupakan hambatan terbesar dalam melakukan pendidikan seks bagi anak disabilitas (88,9\%), kemudian diikuti oleh 11 $\%$ kebijakan sekolah dan kurangnya 
pengetahuan. Lebih dari sebagian $(55,6 \%)$ peserta memperoleh informasi tentang pendidikan seks bagi penyandang disabilitas melalui searching internet dan $33,3 \%$ melalui buku dan majalah.

$$
\text { Kegiatan seminar telah }
$$

dilaksanakan pada hari Rabu tanggal 5 Oktober 2016 yang berlangsung selama 2 jam yaitu dari pukul 10.00 s.d 12.00 wib. Kegiatan ini berlangsung di Aula Panti Sosial Bina Grahita Harapan Ibu (PSBGHI) Kalumbuk dan peserta berjumlah 36 orang. Kegiatan ini dibuka oleh Pimpinan PSBGHI yang diwakilkan oleh Kepala Tata Usaha. Kemudian dilanjutkan dengan penyampaian materi tentang Perkembangan Reproduksi dan Seksual Anak Penyandang Disabilitas, Permasalahan Reproduksi/Seksual pada Anak Disabilitas, dan Upaya Penanganan terhadap Permasalahan tersebut. Pemateri adalah Dosen Psikologi dari Fakultas Kedokteran Universitas Andalas yaitu Ibu Nila Anggreny, M.Psi., Psikolog. Setelah itu dilanjutkan dengan pemutaran video tentang Edukasi Seks pada Anak dan Guru Inspiratif_Miss Thompson selama 20 menit. Selanjutnya diskusi antara peserta dan narasumber yang berlangsung selama 60 menit. 5 orang peserta mengajukan beberapa pertanyaan meliputi: 1) Apa penanganan dan perhatian khusus terhadap permasalahan emosional anak? 2) Apa metode terbaik dalam memberikan pendidikan seks untuk anak disabilitas? 3) Bagaimana cara mengetahui anak melakukan perilaku seksual menyimpang? 4) Bagaimanakah perbedaan penanganan antara anak debil dan imbisil? 5) Apa terapi khusus untuk permasalahan onani dan LGBT?
Semua pertanyaan tersebut dijawab secara tuntas oleh narasumber dan disimpulkan kembali oleh moderator untuk penguatan materi yang telah diberikan.

\section{Tahap akhir}

a. Evaluasi pelaksanaan seminar Seminar berlangsung sesuai dengan perencanaan yang telah ditetapkan bersama mitra dan narasumber. Peserta mengikuti kegiatan dari awal hingga selesai dengan baik dan berpartisipasi aktif dalam sesi diskusi.

b. Penyusunan laporan pelaksanaan seminar

c. Penyusunan rencana tindak lanjut

Setelah pelaksanaan seminar, panitia dan mitra menyepakati akan melakukan tindak lanjut berupa pemeliharaan jaringan dengan mitra dan perencanaan kegiatan lainnya dalam upaya meningkatkan profesionalitas pelayanan bagi penyandang disabilitas.

\section{KESIMPULAN \& SARAN}

Kegiatan seminar mampu meningkatkan pemahaman mitra terhadap permasalahan kurangnya pengetahuan tentang perkembangan seksualitas anak penyandang disabilitas dan upaya penanganan yang dapat diaplikasikan. Selain itu juga dicapai suatu kesepakatan bersama untuk melakukan kegiatan selanjutnya berdasarkan permasalahan mitra.

\section{DAFTAR PUSTAKA}

Dinas Sosial Provinsi Sumatera Barat. (2014). Informasi umum: Pelayanan rehabilitasi sosial 
penyandang cacat mental UPTD

Panti Sosial Bina Grahita

(PSBG) Harapan Ibu Padang.

Padang: Dinsos Prov. Sumbar.

Efendi, M. (2006). Pengantar psikopedagogik anak berkelainan. Jakarta: Bumi Aksara.

Somantri, S. (2007). Psikologi anak luar biasa. Bandung: Refika Aditama.

Sutaat., Widodo, N., Murni, R., Habibullah, Pudjianto, B., Widiantoro, E. (2012). Lembaga pelayanan kesejahteraan sosial pemerintah daerah di era otonomi: Studi di tiga provinsi. Jakarta: P3KS Press. 